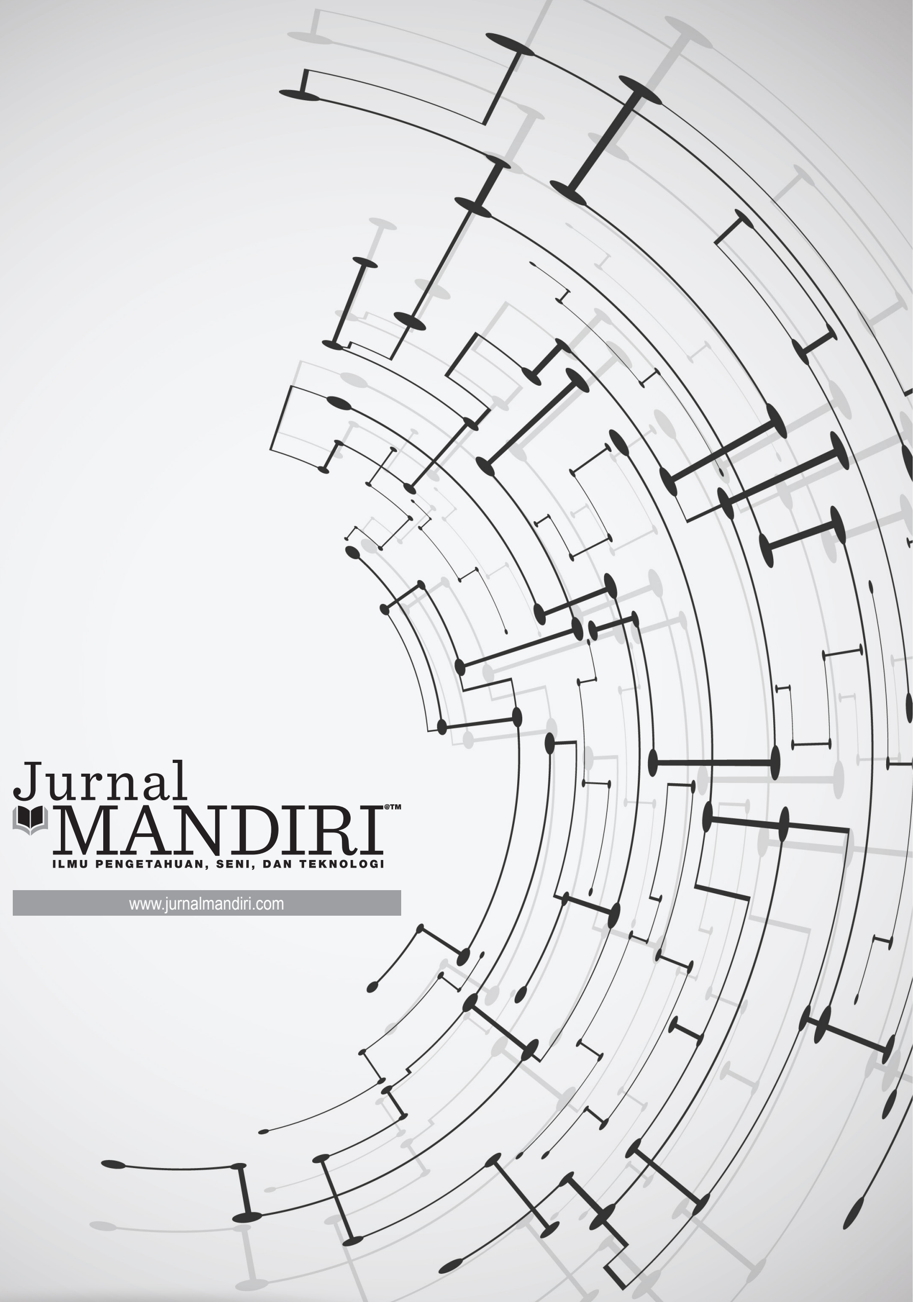


ISSN : 2580-3220, E-ISSN : 2580-4588

J. Mandiri., Vol. 2, No. 2, Desember 2018 (387 - 402)

(C)2018 Lembaga Kajian Demokrasi

dan Pemberdayaan Masyarakat (LKD-PM)

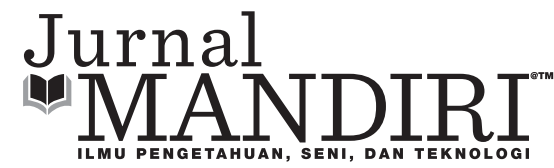

\title{
ANALISIS TINGKAT KEMATANGAN PMO DAN TATA KELOLA PROYEK BERBASIS TEKNOLOGI INFORMASI PADA BANK X
}

\author{
Nefo Indra Nizar \\ Fakultas Ekonomi, Universitas Pamulang \\ nefoindra@gmail.com
}

\begin{abstract}
Abstrak
Di dalam tata kelola proyek, PMO sebagai unit organisasi yang mengawal, memonitor, mengontrol dan mengelola proyek-proyek berbasis teknologi informasi memiliki peran yang sangat penting. Semakin tinggi tingkat kematangan organisasi PMO dan tingkat kematangan proses tata kelola proyek semakin baik di dalam implementasi proyek, mengingat pengembangan proyek teknologi informasi memerlukan biaya yang sangat besar. Penelitian ini bertujuan untuk mengetahui tingkat kematangan PMO dan Tata Kelola Proyek berbasis TI. PMO merupakan fenomena baru di dunia usaha saat ini, khususnya bagi perusahaan yang berbasis proyek mempunyai peran atau fungsi yang berbeda di tiap organisasi. Untuk melihat tingkat kematangan proses Tata Kelola Proyek berbasis TI dan tingkat kematangan organisasi IT PMO di dalam pengelolaan proyek berbasis TI, dilakukan penelitian tingkat kematangan PMO di dalam proses tata kelola proyek dengan menggunakan pendekatan proses tata kelola teknologi informasi COBIT, dan pendekatan teori Hills (2004) mengenai tingkat kompetensi unit organisasi PMO. Tingkat kematangan proses tata kelola proyek saat ini berada pada tingkat 3, atau proses tata kelola sudah didefinisikan secara tepat untuk tujuan bisnis dan teknis (defined process). Tingkat kompetensi organisasi saat ini berada pada tahap 2, atau Basic PMO.
\end{abstract}

Kata Kunci : $\quad P M O$, Tata Kelola Proyek, Tingkat Kematangan

\section{PENDAHULUAN Latar Belakang}

Kegagalan suatu proyek berdampak buruk terhadap kinerja perusahaan. Berdasarkan penelitian Gartner, hampir USD 600 juta dana terbuang percuma setiap tahun akibat kegagalan suatu proyek. Berdasarkan banyak penelitian, pengelolaan proyek menjadi semakin rumit jika semakin banyak proyek yang overlapping di dalam suatu organisasi (Misner, 2008). Untuk itu diperlukan adanya unit organisasi di dalam tata kelola proyek yang bisa mengelola multi-proyek, agar proyek dapat diselesaikan on schedulle, on budget, dan to scope. Bentuk organisasi yang mengelola proyek-proyek di dalam organisasi tersebut adalah PMO.
Manajemen proyek Office (PMO) sudah menjadi fenomena baru di dunia usaha saat ini, khususnya bagi perusahaan yang berbasis proyek (proyek -based organizations), mulai dari industri perbankan, telekomunikasi sampai dengan industri pertambangan dan energi. Banyak perusahaan termasuk perbankan yang memiliki unit organisasi PMO di dalam membantu pengelolaan proyek, termasuk proyekproyek berbasis TI sebagai unit kerja yang mempunyai tugas untuk melakukan perencanaan, koordinasi, monitoring dan pengawasan terhadap jalannya proyek dan memberikan laporan kepada manajemen perusahaan.

Di dalam melakukan pengelolaan proyek 
berbasis teknologi informasi, diperlukan tata kelola proyek yangbaik. tata kelola proyekadalah bagian dari tata kelola teknologi Informasi Perusahaan. Tata kelola proyek diperlukan agar berjalan sesuai dengan peraturan, tujuan dan sasaran bisnis perusahaan. Disamping itu tata kelola proyek diperlukan untuk menghindari resiko yang tidak diinginkan yang bisa berakibat kepada kinerja perusahaan.

Tata kelola proyek yang baik dapat dilihat dari tingkat kematangan, baik dari sisi organisasi, maupun dari sisi perspektif proses. Dari sisi organisasi, dapat dilihat tingkat kematangan organisasi yang bertanggung jawab terhadap semakin baik tata kelola proyek yang dijalankan, sedangkan dari sisi perspektif proses, untuk meyakinkan bahwa strategi di bidang TI dapat mencapai tujuan dan sasaran bisnis perusahaan melalui proyek.

Perkembangan PMO sendiri relatif baru. Menurut Dai dan Wells (2004), PMO mulai dikenal pada tahun 1994 (Hobbs dan Aubry, 2007). Referensi akademik mengenai PMO kemudian mulai muncul dalam bentuk buku dan karya ilmiah pada tahun 2003 (Valle et al., 2008).

Berdasarkan definisi yang diberikan oleh Manajemen proyek Institute (PMI, 2008) pengertian PMO adalah sebagai berikut, "A Manajemen proyek Office (PMO) is an organizational body or entity assigned various responsibilities related to the centralized and coordinated management of those projects under its domain. The Responsibilities of PMO can range from providing manajemen proyek support functions to actually being responsible for the direct management of a project". PMO adalah unit organisasi yang ditugaskan dengan berbagai tanggung jawab berkaitan dengan pengelolaan terpusat dan terkoordinasi proyekproyek berdasarkan domainnya.

Brown et al. (2009) menyebutnya sebagai Project Office, atau Program Management Office (PMO) adalah salah satu unit organisasi yang bertugas untuk meyakinkan dan melakukan koordinasi proyek-proyek pada berbagai tahapan pekerjaan proyek. PMO biasanya terdiri dari staff manajer yang sudah pengalaman di dalam pengelolaan budget proyek, jadwal, sumber daya dan menggunakan tools untuk tetap update terhadap status proyek dari team kerja dan para stakeholder proyek. Tujuannya adalah untuk meyakinkan bahwa proyek tetap berjalan baik dan berhasil.

Berdasarkan literatur mengenai PMO, Hobbs dan Aubrey (2007) mencoba melakukan pengelompokkan PMO yang dilakukan oleh penelitian sebelumnya. Mereka membagi tipologi PMO ke dalam model yang sederhana yang hanya mengelola satu proyek sampai dengan model yang lebih kompleks untuk multi-project.

\begin{tabular}{|l|l|l|l|l|l|}
\hline \multicolumn{5}{|c|}{ TABEL 1. TIPOLOGI PMO } \\
\hline Author & $\begin{array}{l}\text { Single- } \\
\text { Project } \\
\text { Entity }\end{array}$ & \multicolumn{4}{|c|}{ Multi-Project Entity } \\
\hline $\begin{array}{l}\text { Dinsmore } \\
\text { (1999) }\end{array}$ & $\begin{array}{l}\text { Autono- } \\
\text { mous } \\
\text { Project } \\
\text { Team }\end{array}$ & $\begin{array}{l}\text { Project } \\
\text { Support } \\
\text { Office }\end{array}$ & $\begin{array}{l}\text { Manajemen } \\
\text { proyek } \\
\text { Center of } \\
\text { Excellent }\end{array}$ & $\begin{array}{l}\text { Program } \\
\text { Management } \\
\text { Office }\end{array}$ & \\
\hline $\begin{array}{l}\text { Gartner } \\
\text { Research } \\
\text { Group }\end{array}$ & & $\begin{array}{l}\text { Project } \\
\text { Reposi- } \\
\text { tory }\end{array}$ & Coach & & \\
\hline $\begin{array}{l}\text { Crawford } \\
\text { (2002) }\end{array}$ & $\begin{array}{l}\text { Covel-1: } \\
\text { Control } \\
\text { Office }\end{array}$ & $\begin{array}{l}\text { Level-2 } \\
\text { : Busi- } \\
\text { ness Unit } \\
\text { Project } \\
\text { Office }\end{array}$ & $\begin{array}{l}\text { Level-3: } \\
\text { Strategic } \\
\text { Project } \\
\text { Office }\end{array}$ & Enterprise & \\
\hline $\begin{array}{l}\text { Englund, } \\
\text { Graham, } \\
\text { \&Din- } \\
\text { smore } \\
\text { (2003) }\end{array}$ & & $\begin{array}{l}\text { Project } \\
\text { Support } \\
\text { Office }\end{array}$ & $\begin{array}{l}\text { Manajemen } \\
\text { proyek } \\
\text { Center of } \\
\text { Excellent }\end{array}$ & $\begin{array}{l}\text { Program } \\
\text { Management } \\
\text { Office }\end{array}$ & \\
\hline $\begin{array}{l}\text { Kendall } \\
\text { \& Rollins } \\
\text { (2003) }\end{array}$ & & $\begin{array}{l}\text { Project } \\
\text { Reposi- } \\
\text { tory }\end{array}$ & Coach & Snterprise & "Deliver \\
\hline $\begin{array}{l}\text { Garfein } \\
\text { (2005) }\end{array}$ & $\begin{array}{l}\text { Project } \\
\text { Office }\end{array}$ & $\begin{array}{l}\text { Basic } \\
\text { PMO }\end{array}$ & $\begin{array}{l}\text { Mature } \\
\text { PMO }\end{array}$ & Enterprise \\
PMO & \\
\hline
\end{tabular}

Bank X adalah bank baru hasil merger. Integrasi Teknologi Informasi telah dilaksanakan dengan baik. Bank X adalah bank pertama di Asia Tenggara yang berhasil mencapai integrasi penuh di seluruh fungsi platform TI dan Operasionalnya yang dilakukan melalui sistem bisnis tunggal 'big bang' dan pendekatan integrasi TI (Annual Report, 2009). Setelah proses merger. banyak proyek-proyek berbasis TI yang diusulkan, banyak proyekproyek yang sudah berjalan, ada proyek yang berhasil, dan ada pula proyek yang gagal untuk diimplementasikan.

Dari hasil survey penelitian, Standish Group (Hunte, 2007) tingkat keberhasilan proyek TI memang meningkat menjadi 34 persen, tetapi masih sebesar 15 persen mengalami kegagalan, dan sisanya sebesar 51 persen terbentur dengan masalah over budget, behind schedulle, atau project scope. Pada laporan yang dibuat 
oleh Standish Group (John et al, 2010) diidentifikasikan ada 10 faktor kritikal yang bertanggung jawab terhadap suksesnya suatu proyek. Kebalikannya, apabila tidak dijalankan, merupakan faktor penyebab gagalnya suatu proyek.

\section{TABEL 2. CHAOS REPORT SUCCESS FACTORS BY RANK}

\begin{tabular}{l|l|l|l|l|l|l|}
\hline Factor & 1994 & 1998 & 2000 & 2002 & 2006 & 2008 \\
\hline
\end{tabular}

\begin{tabular}{|l|c|c|c|c|c|c|}
\hline User Involvement & 1 & 1 & 2 & 1 & 1 & 1 \\
\hline $\begin{array}{l}\text { Executive } \\
\text { Management } \\
\text { Support }\end{array}$ & 2 & 2 & 1 & 2 & 2 & 2 \\
\hline
\end{tabular}

\begin{tabular}{l|l|l|l|l|l|l|l|l|} 
Support & 2 & 2 & 1 & 2 & 2 & 2 \\
\hline
\end{tabular}

\begin{tabular}{|l|c|c|c|l|l|l|}
\hline $\begin{array}{l}\text { Clear Statement } \\
\text { of Requirement }\end{array}$ & 3 & 6 & 7 & & & \\
\hline Proper Planning & 4 & 8 & & & & \\
\hline
\end{tabular}

Proper Planning

Realistic Expectations

Smaller Project

Milestones

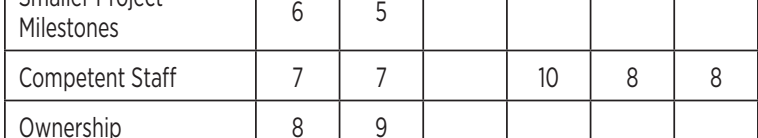

\begin{tabular}{|l|c|c|c|c|c|c|}
\hline Ownership & 8 & 9 & & & & \\
\hline $\begin{array}{l}\text { Clear Vision and } \\
\text { Objectives }\end{array}$ & 9 & 3 & 4 & & 3 & 3
\end{tabular}

$$
\text { Objectives }
$$

Hard-working,

focused Staff

\begin{tabular}{|c|c|c|c|c|}
\hline Manajemen proyek & 4 & 3 & 3 & 6 \\
\hline
\end{tabular}

\begin{tabular}{|c|c|c|c|}
\hline Minimized Scope & 5 & 5 & \\
\hline Standard Tools and & 6 & 7 & 10 \\
\hline
\end{tabular}

\begin{tabular}{|c|c|c|c|}
\hline $\begin{array}{l}\text { Standard Tools and } \\
\text { Infrastructure }\end{array}$ & 6 & 7 & 10 \\
\hline Formal methodology & 8 & 8 & 9 \\
\hline
\end{tabular}

\begin{tabular}{|l|l|l|l|l|l|l|}
\hline Reliable Estimates & & & 9 & 9 & & \\
\hline Agile & & & & 6 & 5 & 6
\end{tabular}

Requirement Process

Optimizing Scope/

Optimization

\begin{tabular}{|c|c|c|c|c|}
\hline & & & & \\
\hline Financial Management & & & 7 & \\
\hline Emotional Maturity & & & & 4 \\
\hline Execution & & & & 9 \\
\hline Other & 10 & 10 & & \\
\hline
\end{tabular}

Dalam perkembangannya, organisasi PMO mengalami proses peningkatan kompetensi sesuai dengan peranan dan fungsinya. Hill (2004), membagi tingkat kompetensi PMO berdasarkan peranan dan fungsinya menjadi 5 tahapan. Lima tahapan ini menggambarkan level Maturity PMO di dalam tata kelola proyek pada organisasi.

Pada Gambar-1.1, menunjukkan kapabilitas PMO yang menggambarkan 5 tahapan kompetensi untuk menggambarkan tingkat kematangan PMO di dalam suatu organisasi.

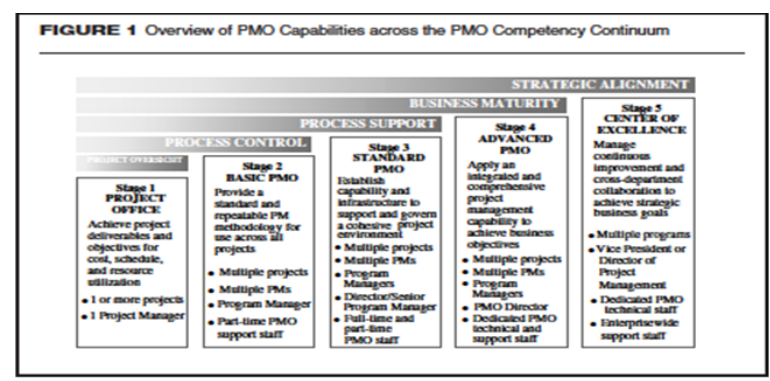

GAMBAR 1. KAPABILITAS PMO BERDASARKAN TINGKAT KOMPETENSI

Sumber : (Hill, 2004)

Salah satu model kematangan kerangka kerja atau manajemen proyek untuk proyekproyek berbasis TI adalah pendekatan kerangka kerja COBIT. Model kematangan COBIT dikembangkan berdasarkan model kematangan dari Software Engineering Institute yang mendefinisikan untuk kapabilitas pengembangan perangkat lunak. Model kematangan dimaksudkan untuk mengetahui keberadaan persoalan yang ada dan bagaimana menentukan prioritas peningkatan (Surendro, 2009).

\section{Perumusan Masalah}

Berdasarkan uraian di atas, maka masalah yang hendak diteliti adalah sebagai berikut :

a. Bagaimana tingkat kompetensi IT-PMO sesuai peranan atau fungsinya di dalam proses tata kelola proyek TI?

b. Bagaimana tingkat kematangan proses tata kelola proyek di Bank X?

\section{Batasan Masalah}

Di dalam penelitian ini diberikan pembatasan pokok masalah, yaitu sebagai berikut :

a. Unit organisasi PMO yang dimaksud adalah IT-PMO yang merupakan salah satu divisi di Direktorat Operations dan IT yang melakukan pengelolaan proyek TI pada Bank Bank X yang berbasis pengembangan software, baik pengembangan software secara in-house, maupun pengembangan software dengan melibatkan pihak eksternal.

b. Unit-unit yang terlibat dalam penelitian ini adalah unit yang berhubungan langsung dengan bagian sistem informasi atau pihak manajemen yang terkait dengan Peranan dan Fungsi yang dilakukan oleh IT- PMO.

\section{Tujuan Penelitian}

Adapun tujuan dari penelitian ini adalah sebagai berikut : 
a. Untuk mengetahui tingkat kematangan IT-PMO di dalam menjalankan proses tata kelola proyek di Bank X.

b. Untuk mengetahui tingkat kematangan tata kelola proyek berbasis TI di Bank X.

\section{TINJAUAN LITERATUR \\ Pengertian PMO}

Dengan semakin pesatnya perubahan lingkungan bisnis, IT Project juga harus bekerja untuk bisa mengikuti perubahan yang terjadi di dunia usaha. Jumlah produk dan jasa yang ingin dikembangkan melalui IT Project menjadi semakin banyak dan kompleks. Untuk itu perlu satu unit organisasi yang dapat mengelola dan melakukan koordinasi multi-proyek.

Brown (Brown, et al, 2009) menyebutkan unit organisasi yang sedang berkembang tersebut adalah Project Office, atau Program Management Office. Program Management Office adalah organisasi yang melakukan koordinasi multi proyek agar dapat diselesesaikan on time, on schedule, dan to scope. Sementara pada beberapa jurnal mengenai manajemen proyek, unit organisasi tersebut banyak menggunakan terminologi Manajemen proyek Office. PMI sendiri menyebutnya dengan Manajemen proyek Office (PMO), unit di dalam organisasi yang tugasnya adalah membantu dan mengelola proyek-proyek sistem informasi teknologi.

\section{TABEL 3. NAMA-NAMA ENTITAS ORGANISASI PMO}

\begin{tabular}{|l|c|}
\multicolumn{1}{|c|}{ Entity } & Percentage \\
\hline Manajemen proyek Office & $59 \%$ \\
\hline $\begin{array}{l}\text { Name containing the term "Project" and somewhat } \\
\text { similiar to manajemen proyek office (e.g. Project } \\
\text { departement) }\end{array}$ & $4 \%$ \\
\hline Project Support Office & $7 \%$ \\
\hline Project Office & $2 \%$ \\
\hline Program Management Office & $12 \%$ \\
\hline Center of Excellent & $2 \%$ \\
\hline No Name & $2 \%$ \\
\hline Other (a great variety with none greater than 1\%) & $12 \%$ \\
\hline \multicolumn{2}{|c|}{ Sumber : (Hobbs, Aubrey, 2007) } \\
\hline
\end{tabular}

Definisi Manajemen proyek Office menurut $\mathrm{PMBOK}$ adalah, "A manajemen proyek office (PMO) is an organizational body or entity assigned various responsibilities related to the centralized and coordinated management of those projects under its domain. The respon- sibilities of $P M O$ can range from providing manajemen proyek support functions to actually being responsible for the direct management of a project", (PMI, 2008). PMO sebagai unit penyedia jasa konsultasi internal mengenai manajemen proyek memiliki peranan dan fungsi yang beragam, tergantung dari besarnya dan tujuan dari organisasi.

Menurut Valle dan kawan-kawan (Valle et. al, 2008) peranan utama dari PMO adalah sebagai berikut :

1. Memberikan support terhadap strategic planning organisasi, portfolio management, dan program management termasuk planning, controlling, dan reporting

2. Pengembangan metodologi, reporting, tools, teknik, template, dan form.

3. Memberikan guideline, standarisasi dan support penggunaan best practice manajemen proyek, termasuk tools, teknik, dan software yang digunakan.

Berdasarkan klasifikasinya, PMO dapat dapat dikelompokkan ke dalam :

1. Strategic PMO, unit PMO yang bertugas untuk melakukan identifikasi, proses pemilihan, dan prioritas proyek dalam kaitannya dengan fungsi strategic planning organisasi.

2. Directive PMO, unit PMO yang bertugas memberikan Guideline, Standard, dan Template penggunaan Best Practice Manajemen proyek, termasuk tools, teknik dan software yang digunakan dalam proses manajemen proyek.

3. Support PMO, unit PMO yang bertugas memberikan support terhadap penggunaan best practice manajemen proyek, termasuk tools, teknik, dan software yang digunakan dalam proses manajemen proyek.

Pinto (2010), mendefinisikan Manajemen proyek Office (PMO) sebagai sebuah unit yang terpusat di dalam organisasi yang tugasnya adalah meningkatkan pengelolaan proyek-proyek. PMO dapat dianggap sebagai Center of Excellent dalam manajemen proyek di banyak organisasi atau perusahaan.

Dengan adanya PMO setidaknya ada tiga manfaat yang diperoleh oleh Project Manager, yaitu : 1) Membantu Project Manager untuk proses scheduling, monitoring, resource allocation, dan controlling proyek; 2) Dengan adanya PMO sebagai fasilitator untuk memberikan program training kepada Project Manager dan 
team proyek untuk menjalankan best practise manajemen proyek; 3) PMO sebagai pusat dokumen dan data proyek. Semua dokumen lesson learned dan dokumentasi proyek, serta Project Status Update untuk proyek yang sedang berjalan, yang dapat digunakan sebagai salah satu sumber referensi dan laporan untuk Project Manager, Team Proyek dan juga untuk kepentingan Perusahaan; 4) PMO sebagai pusat Center of Excellent yang secara terus menerus melakukan proses peningkatan manajemen proyek (Pinto, 2010).

Cooke dan Tate (2011) menyebutkan bahwa PMO adalah unit yang mempunyai peranan untuk meningkatkan kapabilitas manajemen proyek di dalam organisasi. Di samping itu PMO akan membantu untuk memastikan proyek-proyek yang akan, dan sedang berjalan atau yang sudah selesai untuk mengikuti proses tata kelola proyek sesuai dengan peraturan dan prosedur mengenai tata kelola proyek di dalam organisasi. PMO dapat pula membuat standar, guideline, tools, dan template yang digunakan oleh proyek.

PMO adalah unit organisasi yang cukup dinamis, yang terus berubah dari satu peranan dan struktur ke peranan dan stuktur berikutnya. Lebih lanjut dikatakan dari hasil penelitiannya, bahwa perubahan yang terjadi bukan karena karena perubahan karakteristik dan fungsi yang menempel di PMO, tapi lebih kepada proses transformasi yang dinamis yang disesuaikan dengan kebutuhan organisasi untuk mencapai tujuan (Aubrey, et. al, 2010). Sejalan dengan teori organisasi Kontinjensi Struktural (Gudono, 2009), yang mengatakan bahwa untuk menghasilkan kinerja yang terbaik pengelolaan manusia di dalam organisasi tergantung pada beberapa faktor. Teori kontinjensi memberi perhatian terhadap dampak sifat lingkungan pada struktur dan strategi organisasi, jika manajemen menghendaki hasil yang optimal.

\section{Kerangka Kerja Cobit 4.1. tentang Model Kematangan Tata Kelola Proyek}

COBIT (Control Objectives for Information and Related Technology) adalah kerangka kerja mengenai proses Manajemen Teknologi Informasi yang dikeluarkan oleh IT Governance Institute dan banyak digunakan sebagai acuan untuk merancang struktur divisi atau unit teknologi informasi yang sesuai. Tujuan uta- ma COBIT adalah memberikan kebijakan yang jelas dan praktik yang baik dalam tata kelola teknologi informasi dengan membantu manajemen senior memahami dan mengelola resiko terkait tata kelola TI dengan memberikan kerangka kerja tata kelola teknologi informasi dan memberikan panduan yang komprehensif bagi manajemen dan pemilik bisnis proses (Surendro, 2009).

COBIT menyediakan fondasi keputusan dan investasi yang terkait TI. Pengambilan keputusan lebih efektif karena COBIT membantu manajemen dalam mendefinisikan rencana strategis TI, mendefinisikan informasi arsitektur, mendapatkan piranti keras dan piranti lunak TI yang diperlukan untuk menjalankan strategi TI, menjamin pelayanan berkesinambungan, dan pemantauan kinerja sistem TI (Jogijanto dan Abdillah, 2011).

Pada dokumen COBIT 4.1. membagi proses pengelolaan informasi menjadi 4 domain utama (ITGI, 2007) yaitu :

1. Plan and Organize (PO), proses perencanaan dan organisasi yang meliputi strategi dan taktik dan identifikasi cara yang terbaik dari TI untuk mencapai tujuan bisnis.

2. Acquire and Implement (AI), proses pengadaan dan implementasi dalam rangka untuk merealisasikan strategi dan solusi TI yang mendukung strategi bisnis dan implementasi dan integrasi ke dalam proses bisnis.

3. Deliver and Support (DS), proses penyelenggaraan dan pelayanan yang meliputi pelayanan kepada enduser, manajemen data, dan fasilitas operasional lainnya, mengelola sistem keamanan, dll

4. Monitor and Evaluate, proses monitoring dan evaluasi yang mencakup keseluruhan proses teknologi informasi, kontrol internal, tata kelola regulatory dan compliances.

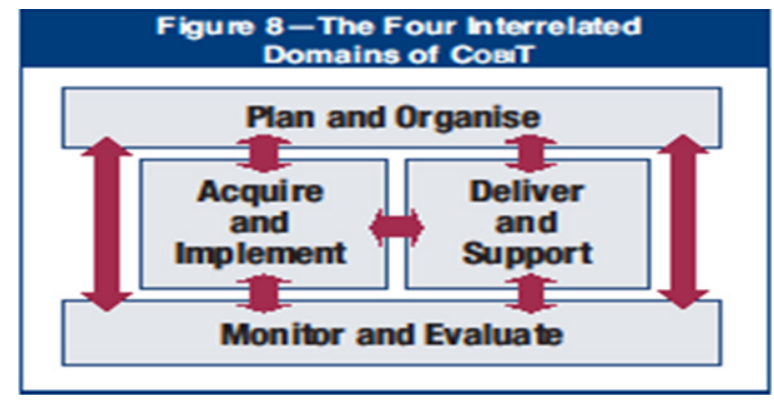

GAMBAR 2. DOMAIN COBIT 4.1. 
Kerangka kerja Program atau Manajemen proyek untuk pengelolaan proyek-proyek berbasis TI dengan pendekatan kerangka kerja COBIT adalah untuk meyakinkan bahwa prioritas proyek dan koordinasi seluruh proyek sudah dilaksanakan dengan baik. Kerangka kerja program atau manajemen proyek termasuk ke dalam domain Plan and Organize (PO) yang mencakup strategi dan taktik, dan perhatian pada identifikasi cara teknologi informasi dapat berkontribusi terbaik pada pencapaian tujuan bisnis. Sementara untuk dapat memenuhi kebutuhan bisnis terhadap TI, manajemen proses pengelolaan proyek harus dapat meyakinkan pada tingkatan mana proses pengelolaan proyek berdasarkan evaluasi organisasi. Evaluasi tingkat kematangan dinilai dari tingkat tidak ada (0), hingga pada tingkat optimis (5).

Model kematangan COBIT dikembangkan berdasarkan model kematangan dari Software Engineering Institute yang mendefinisikan untuk kapabilitas pengembangan perangkat lunak. Model kematangan dimaksudkan untuk mengetahui keberadaan persoalan yang ada dan bagaimana menentukan prioritas peningkatan (Surendro, 2009). Berikut adalah model kematangan proses pengelolaan proyek yang mengacu pada kerangka kerja COBIT 4.1 (ITGI, 2007).

Level-0, Pengelolaan IT Project tidak menggunakan teknik-teknik Manajemen proyek dan organisasi tidak mempertimbangan dampak dari pengelolaan proyek yang salah dan kegagalan proyek terhadap bisnis.

Level-1, Penggunaan teknik-teknik Manajemen proyek dan pengambilan keputusan tergantung kepada individu dan Project Manager. Kurangnya komitmen manajemen terhadap Manajemen proyek dan kepemilikan proyek. Keputusan kritikal terhadap Manajemen proyek dibuat tanpa keterlibatan user dan masukkan dari pengguna. Hanya sedikit atau tidak ada keterlibatan user di dalam mendefinisikan proyek. Struktur organisasi di Direktorat IT tidak jelas terhadap pengelolaan proyek. Tugas dan tanggung jawab pengelolaan proyek tidak dijabarkan. Pro- yek, skedul, dan milestone tidak dijabarkan dengan baik. Penggunaan waktu dan biaya dari team proyek tidak dicatat dan dibandingkan dengan anggarannya.

Level-2, Manajemen senior sudah mulai menyadari dan mengkomunikasikan tentang perlunya IT Manajemen proyek. Organisasi masih dalam proses pengembangan dan sudah mengembangkan beberapa teknik dan metode pengelolaan proyek. Keterlibatan stakeholders di dalam IT Manajemen proyek terbatas. Guideline IT Manajemen proyek sudah mulai dikembangkan. Penerapan pedoman manajemen proyek diserahkan kepada kebijaksanaan individu manajer proyek.

Level-3, IT Manajemen proyek sudah ditetapkan dan dikomunikasikan. IT Project didefinisikan dengan tepat untuk tujuan teknis dan bisnis. Manajemen Senior IT dan Bisnis mulai berkomitmen dan terlibat dalam manajemen proyek IT. PMO dibentuk dengan tugas dan tanggung jawab standar. Monitoring proyek dilakukan berdasarkan milestone, skedul, budget, dan pengukuran kinerja proyek. Manajemen training tersedia, dan atas dasar inisiatif masing-masing individu untuk mengikuti training. Tersedia prosedur Quality Assurance dan Post Implementation Review. Proyek mulai dikelola berdasarkan portfolio-nya.

Level-4, Setelah proyek selesai, manajemen akan meminta kepada proyek formal proyek metrik dan lesson learned untuk di review. Manajemen proyek diukur dan di evaluasi oleh organisasi, tidak hanya oleh bagian IT. Enhancement terhadap proses manajemen proyek dilakukan secara formal dan dikomunikasikan dengan team proyek yang sudah melakukan training. Struktur organisasi proyek selalu dibuat dengan di dokumentasikan tugas dan tanggung jawab masing-masing team sesuai dengan bidangnya. Kriteria evaluasi 
sukses untuk masing-masing milestone sudah dibuat. Value dan Resiko diukur sebelum, selama, dan setelah penyelesaian proyek. Sasaran proyek selalu meningkatkan sasaran organisasi, tidak saja sasaran IT. Terdapat dukungan yang kuat dari manajemen senior, project sponsor atau project owner untuk manajemen proyek. Training yang sesuai diberikan dan direncanakan untuk staff PMO dan untuk unit lain yang ada di IT.

Level-5, Metodologi yang sudah terbukti pada life cycles proyek dan program sudah diimplementasikan, ditegakkan dan diintegrasikan ke dalam seluruh budaya organisasi. Sebuah inisiatif berkelanjutan untuk mengidentifikasikan dan melembagakan best practice Manajemen proyek dilaksanakan. Strategi Teknologi informasi untuk pengembangan sumber dan proyek operasional didefinisikan diimplementasikan. Sudah ada PMO yang terintegrasi yang bertanggung jawab terhadap proyek dan program mulai dari proses Initiating sampai dengan Post Implementation. Perencanaan program dan proyek baik secara lokal maupun regional dijalankan untuk memastikan bahwa pengguna dan sumber daya IT digunakan dengan cara yang terbaik untuk mendukung inisiatif-inisiatif strategis.

\section{Tingkat Kematangan \\ Organisasi PMO Menurut Hill}

Berikut adalah uraian mengenai masingmasing tingkat kompetensi organisasi PMO mulai tahapan Project Office sampai dengan tingkat kompetensi PMO sebagai Center of Excellent.

1. Project Office, Organisasi PMO sebagai Project Office yang bertugas membantu Project Manager untuk menyelesaikan proyek sesuai dengan anggaran, skedul dan penggunaan resources. Support yang diberikan PMO hanya bersifat administratif. Keberhasilan dan kinerja proyek sepenuhnya menjadi tanggung jawab Project Manager. Jumlah proyek yang di support hanya 1 atau lebih proyek saja, dengan 1
Project Manager.

2. Basic PMO, Organisasi PMO bertugas membantu Project Manager menyelesaikan proyek dengan menggunakan metode dasar aplikasi Manajemen proyek dan dilakukan secara berulang. Jumlah proyek yang di support sudah multiple proyek dengan multiple Project Manager. Terdapat seorang PMO manager yang dibantu dengan beberapa staff.

3. Standard PMO. Organisasi PMO sudah memiliki kapabilitas dan perangkat Manajemen proyek yang cukup untuk membantu dan melakukan tata kelola proyek. Peranan dan fungsinya dijalankan secara berulang dan konsisten. Jumlah proyek yang di support sudah multiple proyek dengan multiple Project Manager. Terdapat satu Vice President dan lebih dari satu PMO Manager, yang dibantu dengan beberapa staff.

4. Advanced PMO. Organisasi PMO sudah menerapkan kapabilitas Manajemen proyek secara comprehensive dan ter-integrasi untuk mencapai tujuan bisnis. Peranan dan fungsinya dijalankan secara berulang dan konsisten dan ter-integrasi dengan ruang lingkup multiple projects dan multiple PM dengan dibantu tambahan staff sesuai dengan bidang proyeknya dan tenaga administratif. Terdapat PMO Director/Vice President yang sudah wewenang untuk menentukan kepentingan/ada tidaknya peluang bisnis di dalam lingkungan manajemen proyek yang dibantu oleh beberapa PMO Manager

5. Center of Excellence. Organisasi PMO di dalam menjalankan peranan dan fungsinya sebagai Center of Excellent yang bertanggung jawab secara Bank Wide baik lokal maupun regional di dalam menjalankan best practise Manajemen proyek. Peranan dan fungsi PMO dijalankan secara efektif, efisien dan ter-integrasi. Dalam mengelola proyek, terus menerus melakukan penyempurnaan proses Manajemen proyek, dengan melakukan kolaborasi lintas departemen untuk mencapai tujuan bisnis yang strategis. Organisasi PMO terdiri dari Vice President atau Direktur Manajemen proyek. Beberapa $\mathrm{PMO}$ Manager, staff teknikal dan administratif. 


\section{METODE PENELITIAN \\ Pendekatan Penelitian}

Pendekatan penelitian menggunakan metodologi penelitian kualitatif. Penelitian kualitatif bertujuan untuk mendapatkan pemahaman yang mendalam mengenai situasi yang dihadapi (Cooper dan Schindler, 2008). Penelitian kualitatif bertujuan untuk memperoleh gambaran seutuhnya mengenai suatu hal menurut pandangan manusia yang diteliti.

Penelitian kualitatif merupakan penelitian yang dilakukan berdasarkan paradigma, strategi, dan implementasi model secara kualitatif (Basrowi dan Suwandi, 2008). Secara umum dalam penelitian kualitatif terdapat hal-hal sebagai berikut :

a. Data disikapi sebagai data verbal atau sebagai sesuatu yang dapat ditransposisikan sebagai data verbal.

b. Diorientasikan pada pemahaman makna baik itu merujuk pada ciri, hubungan sistematika, konsepsi, nilai, kaidah, dan abstraksi formulasi pemahaman.

c. Mengutamakan hubungan secara langsung antara peneliti dengan hal yang diteliti.

d. Mengutamakan peran peneliti sebagai instrumen kunci.

Karakteristik penelitian kualitatif berupaya mengungkap keunikan individu, kelompok, masyarakat, atau organisasi tertentu dalam pekerjaannya sehari-hari secara komprehensif dan rinci. Sesuai dengan maksud penelitian ini untuk mendapatkan gambaran secara menyeluruh mengenai peranan PMO dalam pengelolaan proyek-proyek berbasis TI, dimana peranan PMO di tiap organisasi dan perusahaan memiliki ciri dan perbedaan sendiri sesuai dengan kebutuhan perusahaan. Hal ini karena karakteristik penelitian menurut Bogdan dan Taylor (1992), pendekatan kualitatif diharapkan mampu menghasilkan suatu uraian mendalam tentang ucapan, tulisan, dan atau perilaku yang dapat diamati dari suatu individu, kelompok, masyarakat, dan atau suatu organisasi tertentu dalam suatu setting konteks tertentu yang dikaji dari sudut pandang yang utuh, komprehensif, dan holistik (Basrowi dan Suwandi, 2008)

Sebagaimana umumnya penelitian kualitatif, penelitian berdasarkan perspektif interaksionis simbolik bersifat induktif; Peneliti berangkat dari kasus-kasus bersifat khusus berdasarkan pengalaman nyata (ucapan atau pe- rilaku subjek penelitian atau situasi lapangan penelitian) untuk kemudian peneliti rumuskan menjadi model, konsep, teori, prinsip, proposisi, atau definisi yang bersifat umum (Mulyana, 2008).

Sulistyo dan Basuki (2010), menyebutkan bahwa pada penelitian kualitatif model yang digunakan cenderung merupakan proses siklis atau merupakan seri yang tahap-tahapnya dapat bertumpang tindih. Dengan model ini menunjukkan bahwa pada penelitian kualitatif, proses yang berlangsung bersifat nonlinier dan berulang-ulang (iteratif). Penelitian kualitatif memungkinkan subjek penelitian menentukan arah penelitian yang berlangsung. Hal ini mensyaratkan analisis data dilakukan sepanjang masa penelitian dan bukan pada tahap awal sebagaimana pada penelitian kuantitatif.

Salah satu pendekatan penelitian kualitatif adalah dengan cara penelitian lapangan studi kasus yang merujuk pada kajian mendalam tentang ciri aspek, komponen, unsur dan hubungan antara unsur dari suatu kelompok, lembaga, hubungan antar individu maupun organisasi tertentu. Penelitian lapangan merupakan studi terhadap realitas yang ada yang digunakan untuk memahami individu, kelompok, lembaga atau organisasi secara mendalam (Basrowi dan Suwandi, 2008)

\section{Desain Penelitian}

Penelitian kualitatif lebih menekankan proses daripada produk, sehingga dalam hal ini peneliti lebih banyak mempertanyakan "Bagaimana", atau "Mengapa" dari pada "apa" karena proses terjadinya sesuatu itu lebih penting daripada adanya sesuatu (Basrowi dan Suwandi, 2008). Oleh karena itu untuk dapat menjawab pertanyaan penelitian, dibuat desain penelitian, dimulai dengan subjek penelitian, penentuan sampel, penentuan metode pengumpulan data dan analisis data.

\section{Subjek Penelitian}

Subjek penelitian adalah unit organisasi PMO, kerangka kerja PMO, tata kelola proyek, tingkat kematangan PMO dan tingkat keberhasilan implementasi proyek berbasis TI.

\section{Metode Pengambilan Sampel}

Metode pengambilan sampel akan menggunakan sampel secara non-probabilitas (pe- 
milihan non-random) dengan pendekatan Purposive sampling, yaitu pengambilan sampel bertujuan dilakukan dengan mengambil sampel dari populasi berdasarkan kriteria tertentu (Jogijanto H.M., 2008). Untuk menjawab pertanyaan penelitian pada perumusan masalah, sampel yang akan diambil adalah IT-PMO Head, staff divisi PMO, Project Manager, dan unit divisi terkait dengan tata kelola Teknologi Informasi.

\section{Metode Pengumpulan Data}

Data yang dikumpulkan dalam penelitian kualitatif meliputi data observasi, wawancara dengan menggunakan metode semi-structured interviews, angket, dokumentasi serta laporan proyek.

\section{Observasi}

Observasi adalah metode atau cara-cara menganalisis dan mengadakan pencatatan secara sistematis mengenai perilaku organisasi dengan melihat atau mengamati unit organisasi PMO di lapangan secara langsung. Menurut Sutrisno Hadi (1986), observasi merupakan suatu proses yang kompleks, suatu proses yang tersusun dari berbagai proses biologis dan psikologis. Dua diantara yang terpenting adalah proses-proses pengamatan dan ingatan (Basrowi dan Suwandi, 2008). Metode pengumpulan data dengan observasi digunakan bila penelitian berkenaan dengan perilaku manusia, proses kerja, gejala alam, dan bila responden yang diamati tidak terlalu besar.

Observasi berdasarkan jenisnya dapat dibagi 2 jenis (Sulistyo dan Basuki, 2010), yaitu observasi terstruktur dan tidak terstruktur. Ada pula yang membaginya menjadi dua bagian besar, yaitu observasi partisipan, dan observasi nonpartisipan. Observasi tidak terstruktur kadang-kadang disamakan dengan observasi partisipan. Karakteristik observasi tidak terstruktur ialah peneliti tidak memiliki himpunan kategori pertanyaan yang telah ditentukan sebelumnya. Karena itu observasi tidak terstruktur secara relatif merupakan teknik yang luwes serta bermanfaat dalam penelitian penjelajahan (exploratory research).

\section{Kuesioner}

Survey kuesioner, atau lebih populer dengan nama kuesioner merupakan metode paling sering digunakan. Kuesioner adalah per- tanyaan terstruktur yang diisi sendiri oleh responden atau diisi oleh pewawancara yang membacakan pertanyaan dan kemudian mencatat jawaban yang diberikan. Kuesioner mirip dengan wawancara, namun kuesioner memiliki beberapa keuntungan dibandingkan dengan wawancara (Sulistyo dan Basuki, 2010). Keuntungan tersebut adalah sebagai berikut:

a. Administrasi kuesioner lebih murah daripada wawancara.

b. Kuesioner dapat langsung diterapkan pada sejumlah besar perorangan pada waktu yang bersamaan, sehingga pengumpulan data tidak memerlukan banyak waktu.

c. Responden dapat mengungkapkan pendapat mereka sebebas-bebasnya dalam kuesioner dibandingkan dengan wawancara.

d. Responden dalam kuesioner cukup menggambarkan perilaku yang secara sosial diinginkan, sedang dalam wawancara ucapan responden seringkali ditambah dengan gerakan maupun tekanan ucapan sehingga peluang untuk overacting lebih tinggi daripada kuesioner.

e. Kuesioner lebih sedikit deraunya (noise) dibandingkan dengan wawancara, dimana di si pewawancara dalam cara mengungkapkan pertanyaan dapat mengubah makna pertanyaan atau mempengaruhi jawaban.

f. Adanya peluang penafsiran yang berbedabeda menyangkut pertanyaan yang sama.

\section{Wawancara}

Wawancara adalah percakapan dengan maksud tertentu oleh dua pihak, yaitu pewawancara (interviewer) sebagai pengaju/ pemberi pertanyaan dan yang diwawancarai (interviewee) sebagai pemberi jawaban atas pertanyaan itu (Basrowi dan Suwandi, 2008).

Wawancara dapat dibagi menjadi tiga bagian besar (Sulistyo-Basuki, 2010), yaitu wawancara terstruktur (structured interview), wawancara semi-terstruktur (semi-structured interview) dan wawancara mendalam (indepth-interview). Dari segi bentuk pertanyaan, wawancara dapat dibagi menurut wawancara dalam bentuk pertanyaan terbuka (open question) dan pertanyaan tertutup (open-ended question).

Menurut Cooper dan Schindler (2008), 
banyak penelitian kualitatif menggunakan teknik wawancara tidak terstruktur atau semistruktur. Teknik wawancara tidak terstruktur atau semistruktur dalam penelitian kualitatif dapat dibedakan dengan bentuk teknik wawancara terstruktur yaitu :

1. Wawancara dikembangkan berdasarkan percakapan yang terjadi antara pewawancara dan yang diwawancara.

2. Wawancara membutuhkan kreatifitas untuk mengembangkan wawancara.

3. Wawancara menggunakan keahlian yang cukup dari pewawancara untuk mendapatkan dan menggali data yang dibutuhkan.

4. Wawancara membutuhkan pengalaman dan keahlian untuk mendapatkan penjelasan dan elaborasi dari jawaban yang diberikan oleh yang diwawancara.

Bagian ketiga adalah wawancara mendalam (in depth interview) dengan bentuk kurang terstruktur. Wawancara semacam ini mirip dengan diskusi mengenai sebuah subjek, bukan upaya seseorang untuk memperoleh informasi. Tujuan dari wawancara mendalam adalah mengumpulkan informasi yang kompleks, sebagian besar berisi pendapat, sikap, dan pengalaman pribadi. Sasaran wawancara mendalam adalah menyelenggarakan wawancara yang memungkinkan responden membahas secara mendalam sebuah subjek (Sulistyo dan Basuki, 2010).

\section{Dokumentasi}

Dokumentasi adalah semua dokumentasi yang digunakan sebagai salah satu cara pengumpulan data, baik berupa dokumentasi laporan proyek, dan dokumentasi lainnya yang terkait dengan proyek.

\section{Prosedur Pengumpulan Data}

Untuk penelitian ini pengumpulan data dilakukan dengan cara 1) Observasi (pengamatan) lapangan secara langsung untuk mendapatkan data sebenarnya mengenai proses kerja PMO, 2) Wawancara secara mendalam dengan bentuk tidak terstruktur atau semistruktur, 3) Menyebarkan survey kuesioner untuk mendapatkan pendapat atau opini mengenai peranan atau fungsi PMO, tingkat kematangan dan lingkungan organisasi dan manajemen proyek, 4) Studi dokumentasi juga dilakukan untuk mendapatkan data yang tidak dapat diperoleh dari teknik lainnya. Subyek yang menjadi sumber informasi dipilih sesuai dengan fokus dan tujuan penelitian.

Metode wawancara digunakan untuk memperoleh keterangan atau data tentang kejadian atau proses yang oleh peneliti tidak dapat diamati sendiri secara langsung, baik itu di masa lalu ataupun karena tidak memungkinkan untuk hadir ditempat kejadian. Tujuan wawancara adalah untuk mendapatkan data mengenai latar belakang berdirinya unit PMO, peranan PMO pada saat merger, proses peningkatan kinerja PMO serta konfirmasi terhadap kuesioner yang dibuat.

\section{Teknik Analisis Data}

Analisis data dilakukan secara induktif. Analisis data dilakukan bersamaan dengan pengumpulan data. Sulistyo dan Basuki (2010) menyebutkan bahwa salah satu teknik analisis data penelitian kualitatif adalah teknik analisis data yang dikemukakan oleh Miles dan $\mathrm{Hu}-$ berman (1992). Analisis data dilakukan bersamaan dengan proses pengumpulan data. Ada tiga kegiatan analisis data yang dilakukan, yaitu:

\section{Reduksi data}

Reduksi data merupakan proses pemilihan, pemusatan perhatian, pengabstraksian, dan pentransformasian data kasar dari lapangan. Proses ini berlangsung selama penelitian dilakukan, dari awal sampai akhir penelitian. Dalam proses reduksi ini, peneliti mencari data yang benar-benar valid. Ketika peneliti menyangsikan kebenaran data yang diperoleh akan di cek ulang dengan informan lain yang dirasa peneliti lebih mengetahui.

\section{Penyajian data}

Penyajian data adalah sekumpulan informasi tersusun yang memberi kemungkinan untuk menarik kesimpulan dan pengambilan tindakan. Bentuk penyajian antara lain berupa teks naratif, matriks, grafik, jaringan dan bagan. Tujuannya adalah untuk memudahkan membaca dan menarik kesimpulan. Penyajian data juga merupakan bagian dari analisis. Dalam proses ini peneliti mengelompokkan hal-hal yang serupa menjadi kategori atau kelompok satu, kelompok dua, kelompok tiga, dan seterusnya. Dalam proses ini, data diklasifikasikan berdasarkan tema-tema inti. 


\section{Menarik kesimpulan atau verifikasi}

Penarikan kesimpulan hanyalah sebagian dari satu kegiatan dari konfigurasi yang utuh. Kesimpulan-kesimpulan juga diverifikasi selama penelitian berlangsung. Dalam tahap ini peneliti membuat rumusan proposisi yang terkait dengan prinsip logika, mengangkatnya sebagai temuan penelitian, kemudian dilanjutkan dengan mengkaji secara berulang-ulang terhadap data yang ada, pengelompokkan data yang telah terbentuk, dan proposisi yang telah dirumuskan.

\section{PEMBAHASAN}

\section{Tingkat Kematangan IT-PMO}

Berdasarkan hasil pelaksanaan survei dengan menggunakan kuesioner mengenai tingkat kematangan berdasarkan pendekatan COBIT, diperoleh jawaban atas kuesioner tersebut sebanyak jumlah kuesioner yang didistribusikan kepada para responden sebanyak 18 responden. Dari hasil jawaban responden tersebut selanjutnya dibuat rekapitulasi, seperti terlihat pada Tabel 4.

\begin{tabular}{|c|c|c|c|c|c|c|c|c|}
\hline & \multicolumn{8}{|c|}{$\begin{array}{l}\text { TABEL 4. REKAPITULASI DISTRIBUSI JAWABAN } \\
\text { MATURITY LEVEL BERDASARKAN COBIT }\end{array}$} \\
\hline \multirow{3}{*}{ No } & \multirow{3}{*}{ Atribut } & \multirow{3}{*}{ Status } & \multicolumn{6}{|c|}{ Distribusi Jawaban } \\
\hline & & & a & b & c & d & e & $f$ \\
\hline & & & (\%) & (\%) & (\%) & (\%) & (\%) & (\%) \\
\hline \multirow{2}{*}{1} & \multirow{2}{*}{$A C$} & as is & $0 \%$ & $6 \%$ & $33 \%$ & $39 \%$ & $17 \%$ & $6 \%$ \\
\hline & & & $0 \%$ & $0 \%$ & $6 \%$ & $6 \%$ & $28 \%$ & $61 \%$ \\
\hline \multirow{2}{*}{2} & \multirow{2}{*}{ PSP } & as is & $0 \%$ & $11 \%$ & $33 \%$ & $22 \%$ & $33 \%$ & $0 \%$ \\
\hline & & & $0 \%$ & $0 \%$ & $0 \%$ & $17 \%$ & $39 \%$ & $44 \%$ \\
\hline \multirow{2}{*}{3} & \multirow{2}{*}{ TA } & as is & $11 \%$ & $50 \%$ & $17 \%$ & $17 \%$ & $6 \%$ & $0 \%$ \\
\hline & & & $0 \%$ & $0 \%$ & $11 \%$ & $22 \%$ & $44 \%$ & $22 \%$ \\
\hline \multirow{2}{*}{4} & \multirow{2}{*}{ SE } & as is & $0 \%$ & $6 \%$ & $39 \%$ & $44 \%$ & $11 \%$ & $0 \%$ \\
\hline & & & $0 \%$ & $0 \%$ & $0 \%$ & $11 \%$ & $61 \%$ & $28 \%$ \\
\hline \multirow{2}{*}{5} & \multirow{2}{*}{ RA } & as is & $0 \%$ & $11 \%$ & $6 \%$ & $44 \%$ & $33 \%$ & $0 \%$ \\
\hline & & & $0 \%$ & $0 \%$ & $0 \%$ & $6 \%$ & $22 \%$ & $67 \%$ \\
\hline \multirow{2}{*}{6} & \multirow{2}{*}{ GSM } & as is & $0 \%$ & $11 \%$ & $22 \%$ & $50 \%$ & $17 \%$ & $0 \%$ \\
\hline & & to be & $0 \%$ & $0 \%$ & $0 \%$ & $11 \%$ & $44 \%$ & $44 \%$ \\
\hline \multicolumn{3}{|c|}{ As is (Cobit) } & $2 \%$ & $16 \%$ & $25 \%$ & $36 \%$ & $19 \%$ & $1 \%$ \\
\hline \multicolumn{3}{|c|}{ To be (Cobit) } & $0 \%$ & $0 \%$ & $3 \%$ & $12 \%$ & $40 \%$ & $44 \%$ \\
\hline
\end{tabular}

Secara umum dari rekapitulasi hasil kuesioner II-A mengenai tingkat kematangan berdasarkan COBIT pada Tabel 5.10. dapat diperoleh suatu pola kecenderungan data di lapangan tentang tingkat kematangan proses tata kelola proyek, baik yang saat ini (as is) maupun yang diharapkan (to be), sebagai berikut :

a. Sebagian besar responden, untuk proses tata kelola proyek sebanyak 36\% responden memberikan jawaban "d" atas pertanyaan yang berorientasi masa kini (as is).

b. Pada jawaban atas pertanyaan yang berorientasi masa depan (to be), sebagian besar responden, untuk proses tata kelola proyek sebagian besar responden sebanyak $44 \%$ memberikan jawaban "f".

Untuk dapat mendeskripsikan secara jelas hasil analisa dan kajian tentang tingkat kematangan pada masing-masing atribut yang berkontribusi secara langsung pada tingkat kematangan untuk proses tata kelola proyek secara keseluruhan, maka dengan mengacu pada model kematangan COBIT, untuk tiap pilihan jawaban kuesioner dapat dipetakan kedalam nilai kematangan seperti terlihat pada Tabel 5 .

\begin{tabular}{|c|c|c|l|}
\hline \multicolumn{4}{|c|}{ TABEL 5. PEMETAAN JAWABAN DAN NILAI/TINGKAT KEMATANGAN } \\
\hline No. & Jawaban & Nilai Kematangan & \multicolumn{1}{|c|}{ Tingkat Kematangan } \\
\hline 1 & a & 0 & 0 Non-existent \\
\hline 2 & b & 1 & 1 Initial/Ad Hoc \\
\hline 3 & c & 2 & 2 Repeatable but Intuitive \\
\hline 4 & d & 3 & 3 Defined Process \\
\hline 5 & e & 4 & 4 Managed and Measurable \\
\hline 6 & $f$ & 5 & 5 Optimized \\
\hline
\end{tabular}

Dengan mengasumsikan bahwa setiap atribut kematangan mempunyai nilai kontribusi atau pembobotan yang sama terhadap tingkat kematangan tata kelola proyek, maka untuk kedua status (as is maupun to be) tingkat kematangannya secara detail dapat dilihat pada Tabel 6 .

\begin{tabular}{|c|c|c|c|c|c|}
\hline \multicolumn{6}{|c|}{$\begin{array}{l}\text { TABEL 6. NILAI DAN TINGKAT KEMATANGAN } \\
\text { PROSES TATA KELOLA PROYEK }\end{array}$} \\
\hline \multirow{2}{*}{ No. } & \multirow{2}{*}{ Atribut } & \multicolumn{2}{|c|}{ Nilai kematangan } & \multicolumn{2}{|c|}{ Tingkat Kematangan } \\
\hline & & as is & to be & as is & to be \\
\hline 1 & Awareness \& Communication (AC) & 2.83 & 4.44 & 3 & 4 \\
\hline 2 & Policies, standard \& Procedure (PSP) & 2.78 & 4.28 & 3 & 4 \\
\hline 3 & Tools \& Automation (TA) & 1.56 & 3.78 & 2 & 4 \\
\hline 4 & Skills \& Expertise (SE) & 2.61 & 4.17 & 3 & 4 \\
\hline 5 & Responsibility \& Accountability (RA) & 2.89 & 4.39 & 3 & 4 \\
\hline 6 & Goals Setting \& Measurement (GSM) & 2.72 & 4.33 & 3 & 4 \\
\hline & Rata-rata & 2.56 & 4.23 & 3 & 4 \\
\hline
\end{tabular}

Berdasarkan hasil kuesioner mengenai tingkat kematangan tata kelola proyek berdasarkan COBIT, maka dapat diperoleh informasi sebagai berikut : 
a. Tingkat kematangan saat ini (as is) pada proses tata kelola proyek secara keseluruhan berada pada tingkat 3 , atau proses tata kelola sudah didefinisikan dengan tepat untuk tujuan teknis dan bisnis (defined process).

b. Tingkat kematangan yang diharapkan (to be), pada proses tata kelola proyek secara keseluruhan berada pada tingkat 4 atau terkelola dan dapat diukur (managed \& measurable).

Pada gambar berikut dapat dilihat bahwa posisi nyata nilai kematangan rata-rata saat ini (as is) dan yang diharapkan (to be) untuk tiap atribut kematangan. Dengan mengetahui posisi nyata kedua kondisi kematangan tersebut secara tepat, akan diperoleh gambaran tentang skala prioritas dan besarnya usaha sebagai suatu prasyarat yang penting dan perlu bagi setiap atribut utuk melakukan perbaikan.

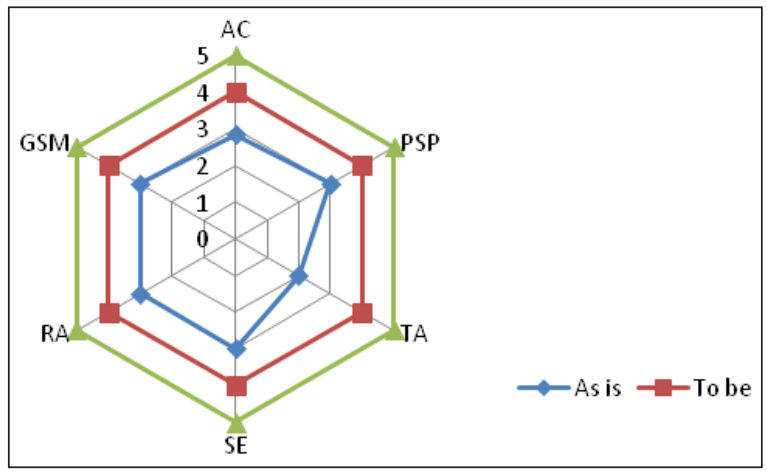

GAMBAR 3. NILAI KEMATANGAN PROSES TATA KELOLA KONDISI SAAT INI (AS IS) DAN KONDISI MASA YANG AKAN DATANG (TO BE)

\section{Analisis Kondisi Tata Kelola Saat Ini (as is)}

Pada kondisi saat ini (as is) sehubungan dengan tingkat kematangan tata kelola proyek, dapat disimpulkan sebagai berikut :

a. Tingkat kematangan tata kelola proyek pada kondisi saat ini (as is) yang memiliki tingkat kematangan paling rendah adalah atribut kematangan Tools and Automation, yaitu tingkat kematangan 2 atau berulang secara intuitive/repeatable. Dalam penetapan prioritas pencapaian improvement proses tata kelola proyek, penggunaan Tools and Automation merupakan prioritas yang perlu disegerakan. Saat ini proses tata kelola proyek oleh IT-PMO masih dilakukan secara manual. Fungsi monitoring dan kontrol serta status proyek masih dilakukan dengan menggunakan excell, sehingga di dalam proses pembuatan laporan ke manajemen, status proyek harus dikumpulkan dahulu dari semua Project Manager. Cara seperti ini memerlukan waktu yang cukup lama dan tidak efisien. Berdasarkan penjelasan dari IT-PMO Head, sebenarnya memiliki tools yang dapat digunakan untuk proses pelaporan dan monitoring, yaitu Rational Focal Point yang merupakan produk dari IBM. Rational Focal Point ini adalah web based platform untuk pengelolaan proyek yang dapat menyimpan semua informasi proyek dalam satu tempat, dengan demikian akan memudahkan untuk proses pelaporan, monitoring dan pengambilan keputusan secara real time.

b. Tingkat kematangan atribut AC, PSP, SE, RA, dan GSM masing-masing mempunyai tingkat kematangan 3, artinya tingkat kematangan tata kelola proyek untuk masingmasing atribut sudah didefinisikan dengan tepat untuk tujuan teknis dan bisnis. IT Manajemen proyek sudah ditetapkan dan dikomunikasikan. IT Project didefinisikan dengan tepat untuk tujuan teknis dan bisnis. Manajemen Senior TI dan Bisnis mulai berkomitmen dan terlibat dalam manajemen proyek IT. PMO dibentuk dengan tugas dan tanggung jawab standar. Monitoring proyek dilakukan berdasarkan milestone, skedul, budget, dan pengukuran kinerja proyek. Manajemen training tersedia, dan atas dasar inisiatif masing-masing individu untuk mengikuti training.

c. Tersedia prosedur Quality Assurance dan Post Implementation Review. Proyek mulai dikelola berdasarkan portfolio-nya.

\section{Analisis Kondisi Tata Kelola yang diharapkan} (to be)

1. Tingkat kematangan seluruh atribut pada kondisi tata kelola proyek yang diharapkan menunjukkan tingkat kematangan yang sama, yaitu 4, terkelola/managed. Semua atribut kematangan akan diarahkan untuk dapat mencapai tingkat kematangan 4, pada proses perbaikan yang akan dilakukan.

2. Pada atribut kematangan AC, diharapkan kebutuhan akan Peranan IT-PMO terhadap tata kelola Proyek-proyek TI secara utuh telah dipahami dan tindakan yang diperlukan sudah diterima secara luas di organisasi. Secara berkala diadakan forum 
internal perusahaan untuk dapat mencari solusi bersama untuk meningkatkan Peranan IT PMO dalam tata kelola proyekproyek TI.

3. Pada atribut kematangan PSP, Kebijakan dan prosedur Peranan IT PMO dalam tata kelola proyek sudah lengkap, yang mengacu pada standar, yang menerapkan internal best practice. Semua aktivitas tata kelola proyek telah di dokumentasikan. Kebijakan dan prosedur tata kelola proyek sudah mendapatkan approval Manajemen.

4. Pada atribut kematangan TA, diharapkan penggunaan tools terkini telah mulai dimanfaatkan sesuai rencana standarisasi penggunaan tools. Beberapa tools telah terintegrasi dengan tools yang lainnya. Tools tersebut digunakan untuk mengotomasi proses monitoring dan controlling proyek.

5. Pada atribut kematangan SE, diharapkan Kebutuhan skill manajemen proyek secara rutin di update untuk seluruh proses tata kelola proyek untuk mendapatkan keahlian dan sertifikasi. Pelatihan formal terhadap staf terkait manajemen proyek telah dilakukan sesuai dengan rencana dan knowledge sharing dilakukan. Dilakukan evaluasi terhadap efektivitas rencana pelatihan.

6. Pada atribut kematangan RA, diharapkan peran dan tanggung jawab tata kelola proyek telah didefinisikan secara jelas, ditetapkan dan dikomunikasikan dalam organisasi. Hal demikian mendukung pemilik proses dalam menjalankan peranannya dengan baik. Ada budaya untuk memberikan penghargaan sebagai upaya memotivasi peran ini.

Surendro (2009) menyebutkan diperlukan strategi pencapaian kematangan dengan pertimbangan sebagai berikut :

1. Tahapan kematangan merupakan proses alamiah dalam proses perbaikan, serta merupakan proses pembelajaran.

2. Sinergi dapat dilakukan secara optimal bila terjadi keseimbangan tingkat kematangan pada keseluruhan atribut.

3. Perbaikan dilakukan secara bertahap sesuai dengan skala prioritas. Atribut dengan nilai kematangan yang lebih rendah mendapatkan prioritas lebih tinggi untuk dilakukan perbaikan.
4. Dengan proses perbaikan secara bertahap sesuai dengan prioritas, maka proses pembelajaran menuju kematangan yang diharapkan (to be) dapat berjalan secara efektif.

Berdasarkan pertimbangan di atas, dapat ditetapkan strategi pencapaian perbaikan proses tata kelola proyek dengan menciptakan sasaran yang diperlukan, dengan skenario sebagai berikut :

1. Atribut dengan tingkat kematangan as is 2, yaitu Tools \& Automation (TA), mendapatkan prioritas utama untuk dilakukan perbaikan, mencapai pada tingkat kematangan 3 terlebih dahulu.

2. Pada kondisi dimana tercapai keseimbangan tingkat kematangan as is untuk semua atribut pada tingkat 3, maka secara bersama untuk seluruh atribut dilakukan langkah perbaikan menuju pada kondisi tingkat kematangan to be, yaitu pada tingkat kematangan 4.

Berdasarkan hasil pelaksanaan survei Kuesioner mengenai tingkat komptensi organisasi IT PMO dengan pendekatan Hill (2004), diperoleh jawaban atas kuesioner tersebut sebanyak jumlah kuesioner yang didistribusikan kepada para responden sebanyak 18 responden. Dari hasil jawaban responden tersebut selanjutnya dibuat rekapitulasi, seperti terlihat pada Tabel 7.

\begin{tabular}{|c|c|c|c|c|c|c|c|}
\hline \multicolumn{7}{|c|}{ TABEL 7. DISTRIBUSI JAWABAN TINGKAT } \\
KOMPETENSI ORGANISASI HILLS (2004) \\
\cline { 4 - 8 } No. & \multirow{3}{*}{ Atribut } & \multirow{3}{*}{ a } & a & b & c & d & e \\
\cline { 4 - 8 } & & & $\%$ & $\%$ & $\%$ & $\%$ & $\%$ \\
\hline 1 & Ko & as is & $28 \%$ & $28 \%$ & $44 \%$ & $0 \%$ & $0 \%$ \\
\hline & & to be & $0 \%$ & $0 \%$ & $28 \%$ & $22 \%$ & $50 \%$ \\
\hline \multicolumn{2}{|c|}{ As is } & $28 \%$ & $28 \%$ & $44 \%$ & $0 \%$ & $0 \%$ \\
\hline \multicolumn{2}{|c|}{ To be } & $0 \%$ & $0 \%$ & $28 \%$ & $22 \%$ & $\mathbf{5 0} \%$ \\
\hline
\end{tabular}

Berdasarkan rekapitulasi hasil kuesioner mengenai tingkat kompetensi organisasi Hills (2004) pada Tabel 7 dapat diperoleh suatu pola kecenderungan data di lapangan tentang tingkat kompetensi organisasi IT PMO, baik yang saat ini (as is) maupun yang diharapkan (to be), sebagai berikut :

a. Sebagian besar responden, untuk Kompetensi Organisasi (KO) sebanyak 44\% responden memberikan jawaban "c" atas per- 
tanyaan yang berorientasi masa kini (as is).

b. Pada jawaban atas pertanyaan yang berorientasi masa depan ( to be), sebagian besar responden, untuk Kompetensi Organisasi (KO) sebagian besar responden sebanyak 50\% memberikan jawaban "e".

Untuk dapat mendeskripsikan secara jelas hasil analisa dan kajian tentang Kompetensi Organisasi, dengan mengacu pada model Kompetensi Organisasi Hills (2004), maka untuk tiap pilihan jawaban kuesioner dapat dipetakan kedalam nilai kematangan seperti terlihat pada Tabel 8 .

TABEL 8. TINGKAT KOMPETENSI ORGANISASI (HILLS, 2004)

\begin{tabular}{|c|c|c|l|}
\hline No. & Jawaban & $\begin{array}{c}\text { Nilai Kompetensi } \\
\text { Organisasi }\end{array}$ & \multicolumn{1}{|c|}{$\begin{array}{c}\text { Tingkat Kompetensi } \\
\text { Organisasi }\end{array}$} \\
\hline 1 & $\mathrm{a}$ & 1 & Project Office \\
\hline 2 & $\mathrm{~b}$ & 2 & Basic PMO \\
\hline 3 & $\mathrm{c}$ & 3 & Standard PMO \\
\hline 4 & $\mathrm{~d}$ & 4 & Advanced PMO \\
\hline 5 & $\mathrm{e}$ & 5 & Center of Excellent \\
\hline
\end{tabular}

Dengan mengasumsikan bahwa atribut kompetensi organisasi mempunyai nilai kontribusi atau pembobotan yang sama terhadap tingkat kompetensi organisasi, maka untuk kedua status (as is maupun to be) tingkat kompetensi organisasi secara detail berdasarkan proporsi distribusi jawaban dapat dilihat pada Tabel 9.

\begin{tabular}{|c|c|c|c|c|c|}
\hline \multicolumn{3}{|c|}{ TABEL 9. NILAI DAN TINGKAT KOMPETENSI ORGANISASI } \\
\hline \multirow{2}{*}{ No. } & \multirow{2}{*}{ Atribut } & \multicolumn{3}{|c|}{ Nilai kematangan } & \multicolumn{2}{|c|}{ Tingkat Kematangan } \\
\cline { 3 - 6 } & & as is & to be & as is & to be \\
\hline 1 & Kompetensi Organisasi $(K O)$ & 2.17 & 4.22 & 2 & 4 \\
\hline
\end{tabular}

Sesuai dengan hasil penelitian pada model kematangan COBIT di atas, dilakukan pembedaan antara nilai kematangan dan tingkat kematangan. Surendro (2009) menyebutkan bahwa nilai kematangan bisa bernilai tidak bulat (bilangan pecahan), yang mempresentasikan proses pencapaian menuju suatu tingkat tertentu, sedangkan tingkat kematangan lebih menunjukkan tahapan atau kelas yang dicapai dalam proses kematangan, yang dinyatakan dalam bilangan bulat.

Berdasarkan hasil kuesioner mengenai tingkat kompetensi organisasi berdasarkan pendekatan Hills (2004), maka dapat diperoleh informasi sebagai berikut :

a. Tingkat kompetensi organisasi IT PMO saat ini (as is) secara rata-rata berdasarkan opini responden berada pada tingkat 2, atau tingkat kompetensi organisasi IT PMO berada pada tahap organisasi Basic PMO.

b. Tingkat kompetensi organisasi IT PMO yang diharapkan (to be) secara rata-rata berdasarkan opini responden berada pada tingkat 4, atau berada pada tahap organisasi Advanced PMO.

Berdasarkan hasil pengamatan penulis tingkat kompetensi organisai IT PMO masih sangat potensial untuk dapat dikembangkan lagi sesuai dengan yang diharapkan (to be). Hal ini tercermin dari jumlah staff yang berada pada organisasi IT PMO masih kurang untuk dapat mengelola jumlah proyek.

Hills (2004) menyebutkan bahwa untuk mencapai kompetensi organisasi PMO tingkat 4, atau Advanced PMO, maka organisasi harus memenuhi kompetensi organisasi PMO tingkat 3 terlebih dahulu atau Standard PMO. Fungsifungsi untuk mencapai Standard PMO yang harus dipenuhi adalah sebagai berikut :

a. IT PMO sebagai pusat dukungan manajemen proyek yang membantu organisasi terkait, yaitu sebagai sumber manajemen proyek untuk bisnis unit, fasilitator untuk manajer proyek, team proyek, dan koordinator untuk semua kegiatan dan keterlibatan semua stakeholders di lingkungan manajemen proyek.

b. IT PMO bertindak sebagai fasilitator untuk proses kematangan manajemen proyek yang digunakan di dalam organisasi.

c. IT PMO sebagai representative di dalam menjalankan manajemen proyek kepada manajemen

d. IT PMO sebagai unit yang dianggap dapat mempengaruhi partsipasi sumber daya proyek untuk menjalankan proyek secara lebih baik sesuai dengan prinsip-prinsip manajemen proyek.

Berdasarkan pengamatan dan pembicaraan dengan IT PMO Division Head, secara fungsi pada tingkat 3, atau Standard PMO, sudah dijalankan oleh organisasi, hanya belum dapat dilakukan secara optimal, sehingga fungsifungsi tersebut belum dapat dirasakan di dalam lingkungan organisasi dan manajemen proyek. Hal ini adalah salah satu alasan untuk menjelaskan jawaban responden yang 
menganggap bahwa kompetensi organisasi kondisi as is masih pada tahapan 2, atau Basic PMO. Penulis melihat peranan tersebut hanya dijalankan oleh satu atau dua orang saja, staf lainnya masih bertindak sebagai tenaga administratif proyek.

Untuk dapat meningkatkan kompetensi organisasi ke tahapan yang diharapkan (to be) 4 , atau Advanced PMO, Hills (2004) menyatakan bahwa selain meningkatkan fungsi atau peranan IT PMO, harus menambah sumber daya IT PMO yang terdiri dari tenaga profesional manajemen proyek dan staf administratif proyek yang dipimpin oleh seorang yang mempunyai kemampuan manejemen proyek praktis dan dapat melihat kebutuhan bisnis, sehingga pengembangan proyek-proyek TI dapat selaras dengan kebutuhan dan strategi bisnis organisasi.

\section{KESIMPULAN DAN SARAN \\ Kesimpulan}

1. Tingkat kematangan proses tata kelola proyek untuk kondisi saat ini (as is) sesuai dengan peranan atau fungsi IT PMO di dalam proses tata kelola proyek TI secara keseluruhan berada pada tingkat 3 , yang berarti proses tata kelola proyek sudah didefinisikan dengan tepat untuk tujuan teknis dan bisnis (defined process).

2. Tingkat kematangan proses tata kelola proyek untuk kondisi yang diharapkan (to be) sesuai dengan peranan atau fungsi IT PMO di dalam proses tata kelola proyek TI secara keseluruhan berada pada tingkat 4 yang berarti terkelola dan dapat diukur (managed \& measurable).

3. Tingkat kompetensi organisasi saat ini (as is) sesuai peranan atau fungsi IT PMO di dalam proses tata kelola proyek TI berada pada tingkat 2, yang berarti tingkat organisasi IT PMO berada pada tahap organisasi Basic PMO.

4. Tingkat kompentensi organisasi yang diharapkan (to be) sesuai peranan atau fungsi IT PMO di dalam proses tata kelola proyek TI berada pada tingkat 4 , yang berarti tingkat organisasi IT PMO berada pada tahap organisasi Advanced PMO.

\section{Saran}

1. Untuk meningkatkan kematangan peranan
IT PMO di dalam proses tata kelola proyek berdasarkan kondisi yang diharapkan (to be), IT PMO perlu memberikan prioritas terhadap atribut Tools \& Automation (TA). Penggunaan Tools \& Automation, mutlak dan harus segera digunakan, terutama di dalam melakukan monitoring \& controlling yang pada gilirannya adalah memberikan laporan secara akurat, cepat kepada manajemen, sehingga keputusan-keputusan strategis dapat segera dapat dilakukan. Selanjutnya secara bertahap meningkatkan dan membuat Kebijakan, Standar dan Prosedur proyek, meningkatkan keahlian personel mengenai manajemen proyek, kesadaran dan komunikasi, yang pada gilirannya akan meningkatkan tanggung jawab dan akuntabilitas IT PMO dan pengukuran serta pencapaian proyek dapat secara fair diterima oleh pihak-pihak yang terkait di dalam proses tata kelola proyek.

2. Untuk meningkatkan kompetensi organisasi IT PMO, perlu ditambah sumber daya yang cukup sesuai dengan jumlah proyek yang dikelola. Meningkatkan kompetensi staff IT PMO yang memiliki sertifikasi manajemen proyek sudah harus dilakukan, sehingga tidak hanya mengandalkan satu atau dua orang saja.

\section{DAFTAR PUSTAKA}

Basrowi dan Suwandi, 2008, Memahami Penelitian Kualitatif, Penerbit Rineka Cipta, Jakarta.

Brown, C.V., DeHayes, D.W., Hoffler, J.A., \& Perkins, W.C, 2009, Managing Information Technology, Sixth Edition, Pearson Education, Inc. New Jersey.

Bank X, 2010, Laporan Tahunan 2010 Bank X, Corporate Secretary, PT Bank X, Jakarta.

Bank X, 2010, Laporan Penyelesaian Proyek Operating Plan 2010, COPS, PT Bank X, Jakarta.

Cooke, H.S., Tate, K, 2011, Manajemen proyek, Second Edition, McGraw-Hill, USA.

Cooper, D.R., Schindler, P.S., 2008, Business Research Methods, International Edition, Mc Graw Hill, New York.

Gudono, 2009, Teori Organisasi, Fakultas Ekonomi \& Bisnis UGM, Pensil Press, Jogja- 
karta.

Hefner, R., 2002, Aligning Strategies : Organizational, Project, Individual, Proceeding of the 36th Hawaii International Conference on System Science, IEEE.

Hill, G.M, 2004, Evolving the Manajemen proyek Office : A Competency Continuum, Information System Management.

Hobbs, B., and Aubrey M., 2007, A Multi Phase Research Program Investigating Manajemen proyek Office (PMOs): The Result of Phase 1, Manajemen proyek Journal, Manajemen proyek Institute.

Hobbs, B., Aubrey, M., Muller, R. \& Bloquiz $\mathrm{T}, 2010$, Identifying Forces Driving PMO Changes, Manajemen proyek Journal, Manajemen proyek Institute.

Hobbs, B., and Aubry, M., 2008, An Empirically Grounded Search for a Typology of Manajemen proyek Office, Manajemen proyek Journal, Manajemen proyek Institute.

Iman Soeharto, 1999, Manajemen Proyek, Edisi Kedua, Jilid 1, Penerbit Erlangga, Jakarta.

Jogiyanto HM.,dan Willy Abdillah, 2011, Sistem Tatakelola Teknologi Informasi, Penerbit Andi, Yogyakarta.

Jogiyanto HM., 2008, Metodologi Penelitian Sistem Informasi, Penerbit Andi, Yogyakarta

John, C.G., Gray, G.R, Gold, A.H, \& Miller, D.W, 2010, Strategies for Improving Systems Development Project Success, Issues in Information Systems, Volume XI, No.1.

Keating, D., 2009, How Does The Manajemen proyek Office Deliver Value to the Organization, a Research Project, National University of Ireland, Galway.

Kendrick, J., 2009, Measures and Metric for PMO Success, Manajemen proyek Office Summit, Kendrick@p2c2group.com.

Lee, L.S, and Anderson, R.M, 2006, An Exploratory Investigation of the Antecedents of the IT Manajemen proyek Capability, e Service Journal.

Misner, J., 2008, The Role of the Manajemen proyek Office in Multi-Project Environtment: Enhancing Governance for Increased Project Success Rate, University of Oregon, Applied Information Management Program.

Mullaly, M., 2006, Longitudinal Analysis of Manajemen proyek Maturity, Manajemen proyek Journal, Manajemen proyek Institute, Vol 36, No.3.
Mulyana, D., 2008, Metodologi Penelitian Kualitatif, Remaja Rosda Karya, Bandung.

Pinto, J.K, 2010, Manajemen proyek Achieving Competitive Advantage, Second Edition, Pearson Education Inc, New Jersey.

Manajemen proyek Institute, 2008, A Guide to the Poject Management Body of Knowledge (PMBOK Guide), Fourth Edition, Manajemen proyek Institute, Inc.Pennsylvania

Rainer Jr., R.K., Turban, E., 2009, Introduction to Information Systems, Second Edition, John Wiley \& Sons, Inc, Asia.

Sulistyo dan Basuki, 2010, Metode Penelitian, Penaku, Wedatama Widya Sastra, Jakarta.

Surendro, K., 2009, Implementasi Tata Kelola Teknologi Informasi, Penerbit Informatika, Bandung

Thompson Jr A.A., Strickland III, A.J, and Gambler, J.E, 2010, Crafting \& Executing Strategy, The Quest for Competetive Advantage, 17th Edition, McGraw-Hill, New York.

Valle, J.A.S., Silvia, W.D.S., \& Soares, C.A.P, 2008, Manajemen proyek Office (PMO) Principles in Practice, Acee International Transactions. 